\title{
NEW VISIONS OF THE PAST - TECHNOLOGY AND THE CREATION OF MEMORY SPACE IN SOUTH AFRICAN MUSEUMS
}

\author{
VICKI LEIBOWITZ \\ School of Architecture and Design \\ Royal Melbourne Institute of Technology University \\ GPO Box 2476V, Melbourne, VIC 3001, Australia \\ Vicki.dan@gmail.com
}

\begin{abstract}
Post-Apartheid South Africa is demanding a revised approach to the construction of museums and memory space, seeking to identify a new form of museum that assists in reflecting the history of Apartheid while facilitating community growth and commonality. This paper examines two differing approaches: The Apartheid Museum in Johannesburg; and The Red Location Museum near Port Elizabeth. Both museums present evolving solutions to the challenge of creating meaningful museum space and exemplify how design technology is responding to emerging questions of how to deal with recent and emotionally raw historical events. The Apartheid Museum follows the experientially based linear model to create a simulated sense of history incorporating persuasive architecture with digital technology. In so doing a slick, international package of the past is produced. In contrast, The Red Museum re-thinks the mode of construction, materiality and linear narrative tradition in museums to create a new kind of space, open and flexible, which is situated in the heart of the township it serves. Dignified and refined, this museum re-positions the past as an entity in the present, acknowledging and celebrating a uniquely African mode of understanding and conveying history. Both regarded as highly successful in their own right, the museums identify ways in which new technology can be applied in the construction of current historical narratives and reveal how technologies can be redirected to allow for the emergence of new perspectives. In this respect, architecture contributes to the construction of new political narratives, using space and technology to subtly convey emotive messages around historical events.
\end{abstract}

\section{Introduction}

Post-Apartheid South Africa presents a particularly interesting position from which to gain insights into how technology is affecting differing approaches to the construction of national narratives. This is pertinent in a post-9/11 world fascinated by sites of memory and acts of memorialization. South Africa casts light on new approaches to the construction and facilitation of memory because, after the demise of Apartheid, it began a radical re-examination of existing approaches to the past, in terms of its potential to reveal commonality between people and to use this to facilitate healing in the community (Omar 53). Interestingly, how we acknowledge and access the past, our own memories of it and official narratives are increasingly determined 
by new technologies- building, communication and museological - that frame and evolve the past in significant ways.

Traditionally museums and memorials of Apartheid South Africa were utilized as physical embodiments of the dominant ideology. Museums were off-limits to black South Africans and their mode of communication highlighted this fact. Large imposing architecture and a static mode of display disregarded the African emphasis on oral tradition and told a deliberately constructed narrative of the past. Joe Noero elucidates that the Apartheid-era approach to memory was one of erasure (the ongoing destruction of selective traces of the past in the present) and clearance (the erection of a barrier so that no knowledge can leak through into the present) (187). This act of selective remembering ensured that the dominant ideology became the only version of the past, dismissing the existence of alternative narratives and disregarding the possibility of personal memory.

To counter this divisive and destructive approach to the past, the post-Apartheid government sanctioned a totally new and open approach to the act of memorializing. To this end, the Truth and Reconciliation Commission was established, to (among other things) bring personal memory to the fore and establish a collective unity. Official institutions of the state were called upon to assist in the facilitation of new narratives and the construction of memory in a way that would acknowledge its place as a living entity in the society (Hall 175). The German theorist Andreus Huyssen identifies this part of memory as a state of being - between living the event and the act of recalling it. He identifies this state as a 'twilight' - the nexus between the past and its recollection. Acknowledging this state renders memory a contemporary act dependent on a past that is understood and altered according to perception, time and representation. Huyssen argues that the role of museums needs to shift away from its traditional position as purveyor of inarguable truth to that of spreading knowledge through its place in the world of spectacle and mass entertainment (2). The use of technology has thrust the notion of museum into question as the real, the authentic and the original become simultaneously valued and abandoned amongst the plethora of the unreal, the hyper-real and the mass produced.

In many ways it is this acknowledgement of the past as an entity in the present that has allowed for memory space to emerge as a dynamic and fluid environment rather than the static stoic version of the past. This, in combination with a celebration of the potential inherent in the tools of mass media has led to a re-visioning of how museums are understood and how they are constructed. It should be noted that this is an active approach to the structure of memory making as opposed to the different question of how to handle the remnant architecture of an existing regime. Neil Leach, Lynn Meskell and Annie E. Coombes amongst others examine this question in detail. In the course of this paper, I will examine two relatively recent museums that have emerged in South Africa. The Apartheid Museum in Johannesburg and The Red Location Museum, just outside Port Elizabeth. Both use technology quite differently to establish diverse approaches to dealing with the past, one aimed at a local community, the other at the international.

\section{Experiential Architectures - The Apartheid Museum}

The Apartheid Museum is a form of 'experiential' architecture, designed according to a didactic linear narrative. It is based on the style utilized in the United States Holocaust Museum, which iconically established this mode of reflecting history (Linenthal 55). The museum is contemporary in its style and use of materials, very firmly establishing itself within the framework of international museum. The experiential approach to museum design is partially based on the realization that the object-based museology is no longer effective in stimulating interest in the past (Hein 8). Consequently museums have been developing new approaches to the construction of museum space and the mode of display in order to immerse visitors in a sense of history by simulating historical narratives. This approach acknowledges the need for museums to compete with the entertainment industry for commercial success but treads a fine line between simulation and entertainment, authenticity and theatricality. The decision to create such a museum in South Africa was born out of a desire to expand Gold Reef City, a pseudomining town and theme park in Johannesburg, into a casino. In order to gain approval for the casino's construction, the company had to agree to produce a 'social development' project. The museum was identified as a means to increase tourism, stimulate the economy and create employment (Findley 125). The context in which this museum was formed surely contributes to its style of production and the audience that it is seeking. In many ways this relationship highlights the way in which the past is readily transformed into a consumable commodity, available for bartering and shaped according to the politics of its creators. Thus in order to be situated within an international context- both in terms of audience appeal and international 
recognition, the Apartheid Museum seeks to align itself with similar styles of museums around the world. Unfortunately it does so regardless of the level of appropriateness of this style to the South African context.

Architecturally the Apartheid Museum, designed by Mashabane Rose Architects, is modern and sophisticated in style. The experience of visiting the museum is strictly controlled so that the progression through history is articulated as a singular powerful narrative. The architecture is utilized to convey a literal story of South Africa's policy of segregation and discrimination. From the point of entry where visitors are assigned identities as 'whites' or 'non-whites' and directed along separated paths of concrete, steel mesh and photographic evidence of passbooks, the architecture facilitates a simulation of the realities of Apartheid. The visitor is guided along a seamlessly linear, evocative path that emotionally resonates due to the controlled lighting, sound and enveloping displays which detail facts of the Apartheid regime. Hard clean lines and a palette of concrete, barbed wire and mesh indicate the lovelessness of a regime, unbending in its brutality. Architect Jeremy Rose refers to it as an "austere prison aesthetic . . . that kind of inhuman space" (qtd. in Swarns). This mode of conveying history relies largely on the combination of evocative architecture that directs the visitors' journey through the space and multimedia technology to intensify the emotive, visceral impact of the experience. The narrative is spelt out in literal architectural terms. Take for example, the $18 \mathrm{~m}$ tall 'pillars of the constitution', which form the entry to the complex, each with one of the seven principles of the constitution written upon them. Or the use of darkened, concrete exhibition spaces with mesh display cases for artifacts, which allow views between exhibits but do not permit freedom of movement. Or the increased lighting as the narrative moves towards the realm of the new South Africa. Sound effects, lighting and projections all contribute to the impact of the narrative, so that one feels victimized, disoriented and uncomfortable within the display.

However this mode of articulating the past is problematic on numerous levels. It fails to identify a uniquely South African voice or outlook and does not acknowledge the call for diverse perspectives rather presenting a fixed authoritative position on the past. Perhaps most significantly, in aiming for the tourist market it perpetuates the alienation of the local audience reducing Apartheid to a slickly packaged contemporary consumable. Rather than acknowledging that the legacy of Apartheid cannot be confined to a singular narrative, this museum suggests that the past and the present are separate entities articulating the specifics of the past in a generic and exclusionary manner. By suggesting that Apartheid can be understood in a linear way, the museum positions itself as a Western icon, failing to embody the African perspectives that it claims to celebrate.

Yet the museum succeeds in affecting visitors who find it very moving. The clean modern lines and the refined aesthetic of the architecture and interior display are recognizable to an international museum-going audience so that the history of Apartheid is conveyed in recognizable terms. Technology is utilized in way that is familiar, sophisticated and urbane, ironically displaying the horrors of Apartheid within the safe confines of a sanitized and refined context. The narrative of Apartheid has been somehow transformed and repackaged into a global and familiar history. Through the use of an international architectural language refined and slickly modern, and conveyed with multimedia presentations, the history of South Africa assumes a different meaning. This propels it away from its origins as a uniquely African event or experience and generalizes it. It may be argued that this is appropriate for the international audience to whom the museum is aimed in part - making the horrors of Apartheid accessible and understandable to them, but in so doing, it removes it as a personal and local experience. The mode of conveying historical fact becomes fluid and encompassing, but the experience itself is tightly controlled and linear. Rather then facilitating the multiple perspectives of a Rainbow Nation, this controls the narrative and delivers the singular truth of the official postApartheid narrative. In modernizing and applying the latest pedagogical approach to memory making, this Museum proffers a step backwards rather than a step forwards.

In her analysis of the workings of the Truth and Reconciliation committee Beth S. Lyons discussed the importance of articulating the details of the past in order to claim ownership of it (par.4.). The act of identifying what happened to whom, when and why is significant in allowing people to come to terms with the past. Contrarily then, this museum generalizes the past, reducing the specificity of both the events and the act of Apartheid itself to a universal 'bad act'. The empowerment inherent in laying claim to a unique past - specifically South African- is radically undermined by its re-situation in an international context. Where the Truth and Reconciliation Commission succeeded was in its personalization of Apartheid, its desire to articulate the specifics of the past and to dismantle the sense of Apartheid as a faceless regime. However in order to construct its narrative for a tourist audience, one with an expectation of 
readily accessible entertainment and polished presentation, the past becomes generalized. That is not to say that there is not a place for a didactic museum such is this, for the tourist market is very important for the South African economy and the story of Apartheid is an important one to tell. Merely that the solution used here is to apply the technological approach of the United States Holocaust Museum in an attempt to compete internationally, rather then using the successful mechanisms of the design and applying them in a uniquely African way.

\section{Socially Integrated Architecture - The Red Location Museum}

In contrast, the Red Location Museum is constructed with a revised approach to the making of memory space. Technology is used here to generate a new form of museum, one that more accurately reflects the culture and physical environment from which it comes. Unlike the traditional approach of distinguishing the museum through physical separation from residential areas (thus highlighting it as a civic institution), the Red Location Museum is sited within the urban fabric of the community that it serves. In so doing, it becomes integrated into the daily act of coming to terms with the past. The museum is part of a precinct in the city centre designed to reinvigorate the city, with the understanding that the ongoing process of dealing with the past will be central to that growth and prosperity within the city. Stylistically, the museum incorporates a language appropriate to its context utilizing the inexpensive, readily available and often architecturally disregarded materials of the township in its construction. Corrugated steel, tin and concrete are used to generate a museum of its people, for its people. Externally the edifice is shaped to reflect the industrial aesthetic, for the heroes of this community were Union workers. Its sawtooth roofline is visible above the shacks that make up much of the township it but the scale and materiality remains in keeping with the context there (Findley 141).

Internally it is arranged to encourage an open non-linear exploration of the space - physically open and ideologically encouraging personal interpretation and reflection. The experience of visiting the museum is one that is organic and fluid - so that the narrative of the past can be understood in any number of ways. The central space comprises memory boxes, giant enveloping cases that give a nod to traditional modes of display. Rather than glass, these boxes are clad in corrugated iron and filled with individual and personal accounts of the past. Reminiscent of the Memory Boxes carried by itinerant workers that contained all their precious possessions and tokens of home, these spaces containing everyday items, voice-over stories and images, are poignant and poetic interpretations of a cultural and social icon. The transformation of an African social symbol of precious memory - the Memory Box - into a physical space that can be inhabited and understood on those terms assists in aligning the narrative of the past with personal recollection. The boxes themselves are $6 \mathrm{~m}$ square in plan and $12 \mathrm{~m}$ tall, poetic and impressive in scale and size. As if to highlight the need to understand the old in new contexts, the architects have utilized standard steel windows in new ways and applied a rigor to the construction of the concrete blocks imbuing a typical township material with the worth and value of facing brick (Slessor 42). In so doing, the museum generates a new form of memory space, a type of South African museum that is unique in its conception and construction. By reconfiguring the mode of display along with the form and experience of the space, the architects begin to shift traditional notions of what a museum is in the minds of the previously marginalized population. The openness of the design, and its siting in a contemporary sphere, physically, visually and ideologically have all placed the Red Location Museum at the centre of community invigoration and rehabilitation.

Another aspect of the revitalization of the community occurred through the employment of local people in the Museum's construction. Teams of local workers were rotated on the job learning the trade and earning money, ensuring that the act of creating the museum itself became a physical embodiment of the process of intertwining the past with the present. This practical application of knowledge allowed the museum to facilitate a bridge between coming to terms with the past and taking ownership of it in the present. By incorporating familiar building materials in the context of an unfamiliar typology and constructing a new type of museum - one which allows for personal interpretation and oral narratives - the Red Location Museum encourages a rediscovery of the nature of the museum and assists in establishing a personal connection between the local people and the museum that represents their past. This does not mean patronizing the visitor, nor reducing the past to a formulaic experience, but rather allowing for personal reflection on the past and restoring dignity and beauty to sites, materials and modes of constructing narratives that were formerly disregarded as second rate.

Memory in this context is also employed to facilitate economy, but rather than generating an economy based on the consumption of the past, it is based on its production. Furthermore, this economy is based on the transmission of technology and skills to the community for the 
present. In this manner the Red Location museum allows for the act of reconciliation with the past to contribute to a productive and prosperous present and future. Rather than identifying Apartheid as a contained entity that can be packaged and displayed, this museum acknowledges the nebulous state of memory and celebrates its ongoing place within the society. It articulates the weightiness of the facts of the past and draws them into the present allowing the effects of the past to manifest in the 'twilight' space articulated by Huyssen. In so doing the museum allows for individual recollections and identifications of the past and facilitates unique narratives based on an oral tradition. Architecturally it also incorporates a sophisticated language creating refined modern spaces but grounded in a uniquely African identity. In this respect technology allows for the traditional materials and spaces to be reconceived in a specific modern context- post Apartheid South Africa.

\section{Conclusion}

In seeking to ground current memory practice in the present, South Africa is endeavoring to incorporate numerous facets of technological advances in order to generate new, more meaningful architectural space. Straddling both the international and local markets, South Africa is attempting to produce new museums that appropriately deal with the raw and recent past of Apartheid. The Apartheid Museum, presents a slick urbane version of the past - utilizing digital language, in conjunction with powerful evocative architecture to situate the past in an international setting and to appeal to a tourist market. By contrast, The Red Location Museum applies technological advances in its use of low cost indigenous materials and redefinition of the basic museum modality to facilitate the construction of a more real, local environment through which to come to terms with the past. Both proffer a physicalized solution to dealing with the past, providing a new "untainted" space from which to construct new narratives. Both acknowledge the significant role that architecture can play in highlighting commonality and use physical space to convey specific meaning around the past and hope for the future.

\section{References}

Annie E Coombes. Visual Culture and Public Memory in a Democratic South Africa: History After Apartheid. Durham and London: Duke University Press, 2003.

Findley, Lisa. Building Change: Architecture, Politics and Cultural Agency. London and New York: Routledge, 2005.

Hall, Janet. "Museums, myths and missionaries: redressing the past for a New South Africa." Museum, Media, Message. New York: Routledge, 1995.

Hein, Hilde S. "From Object to Experience." The Museum in Translation. Washington and London: Smithsonian Institution Press, 2000.

Huyssen, Andreas. Twilight Memories: Marking Time in a Culture of Amnesia. New York: Routledge, 1995.

Leach, Neil. "Erasing the past, The 'denazification' of post-apartheid Johannesburg and South Africa", in Neil Leach (ed.). The Hieroglyphics of Space: reading and experiencing the modern metropolis, London and New York: Routledge, 1995.

Linenthal, Edward T. Preserving Memory, The Struggle to Create America's Holocaust Museum. Harmondsworth: Viking Penguin, 1995.

Lyons, Beth S. "Between Nuremberg and Amnesia: The Truth and Reconciliation Commission in South Africa." Monthly Review 49, 4 (September 1997).

Meskell, Lynn. "Trauma Culture - Remembering and forgetting in the New South Africa", in Duncan Bell (ed.). Memory, Trauma and World Politics; reflections on the relationships between past and present. New York: Palgrave McMillan, 2006.

Noero, Joe. "Architecture and Memory", in Linda Kraus and Patrice Petro (eds.). Global Cities: Cinema, Architecture and Urbanism in A Digital Age. USA: Rutgers University Press, 2003.

Omar, Rooksana. "Meeting the Challenges of Diversity in South African Museums." Museum 57, 3 (2005): 52-59.

Slessor, Catherine. "Memory and Struggle." Architecture New Zealand 5 (2006).

Swarns, Rebecca. "Oppression in Black and White South African - Museum recreates Apartheid." New York Times, 10 Dec. 2001. 